\title{
First bird remains from the Eocene of Algarrobo, central Chile
}

\author{
Roberto E. Yury-Yáñez ${ }^{1}$, Rodrigo A. Otero ${ }^{2}$, Sergio Soto-Acuña ${ }^{3}$, Mario E. Suárez ${ }^{4}$, \\ David Rubilar-Rogers ${ }^{2}$, Michel Sallaberry ${ }^{1 *}$
}

\author{
I Laboratorio de Zoología de Vertebrados, Departamento de Ciencias Ecológicas, Facultad de Ciencias, Universidad de Chile. Las \\ Palmeras 3425, Ñuño, Santiago, Chile. \\ 3 Laboratorio de Ontogenia y Filogenia, Departamento de Biología, Facultad de Ciencias, Universidad de Chile. Las Palmeras 3425 , \\ Santiago, Chile. \\ *Corresponding author.msallabe@uchile.cl
}

\begin{abstract}
Paleogene records of birds in the Eastern margin of the Pacific Ocean have increased in recent years, being almost exclusively restricted to fossil Sphenisciformes (penguins). New avian remains (Ornithurae, Neornithes) from Middle-to-Late Eocene levels of the Estratos de Algarrobo unit, in Algarrobo, central Chile, are disclosed in the present work. These new finds are significant in representing the first non-spheniscid bird remains of Middle to Late Eocene age, recovered in mid-latitudes of the eastern Pacific and probably belonging to a procelarid. It complements the regional record of Eocene birds, previously known only at high-latitudes such as Seymour Island (Antarctica) and Magallanes (Chile), and low-latitude locations in Peru.
\end{abstract}

Keywords: Birds, Eocene, Biogeography, Algarrobo, Chile.

RESUMEN. Primeros restos de aves del Eoceno de Algarrobo, Chile central. Los registros de aves paleógenas en el margen oriental del Océano Pacífico se han incrementado en los últimos años, estando casi exclusivamente restringidos a Sphenisciformes fósiles (pingüinos). Nuevos fósiles avianos (Ornithurae, Neornithes) provenientes de niveles del Eoceno Medio a Tardío de los Estratos de Algarrobo, en Algarrobo, Chile central, son dados a conocer en el presente trabajo. Estos nuevos hallazgos son significativos en representar los primeros restos de aves no-spheníscidos de edad Eoceno Medio a Tardío, recuperadas en latitudes intermedias del Pacífico oriental y probablemente pertenezcan a un procelárido. Este hallazgo complementa el registro regional del grupo durante el Eoceno, anteriormente conocido en localidades de altas latitudes como isla Seymour (Antártica) y Magallanes (Chile), y localidades de bajas latitudes en Perú. 


\section{Introduction}

The fossil record of birds from Chile is especially well-represented during the Neogene, with finds recovered from levels of the La Portada Formation (Ferraris and Di Biase, 1978), Bahía Inglesa Formation (Rojo, 1985 emmended by Marquardt et al., 2000) and Coquimbo Formation (Moscoso et al., 1982), in the northern area of the country (e.g., Walsh and Hume, 2001; Emslie and Guerra Correa, 2003; Acosta Hospitaleche et al., 2006; Walsh and Suárez, 2006; Sallaberry et al., 2007; Mayr and Rubilar-Rogers, 2010), being mostly comprised by marine taxa (Chávez, 2007). The fossil record of continental birds is restricted to Meganhiga chilensis, Alvarenga (1995) from Miocene levels correlated with Curamallín Formation (Niemeyer and Muñoz, 1983) in Lonquimay, south-central Chile and an isolated tarsometatarsus of Milvago sp. from La Portada Formation, Antofagasta (Emslie and Guerra Correa, 2003).

To date, the Paleogene record of birds from the eastern margin of South America is known from localities in the southernmost part of the continent, and low-latitude localities, some of them near the Equator. The southernmost record of fossil birds in South America comes from the Leticia Formation (late Middle Eocene), Tierra del Fuego, Argentina, where an associated pelvic girdle and limb were recovered and assigned to Pansphenisciformes indet. (sensu Clarke et al., 2003). From the San Julián Formation (?Late Eocene-?Early Oligocene), southernmost Argentina, came two stem penguin belonging to extinct species: Arthrodytes andrewsi (Ameghino, 1901) and Paraptenodytes robustus (Ameghino, 1895). Their systematic position has been revised by Acosta Hospitaleche (2005) confirming their stem position. Southern discoveries also include indeterminate penguin remains (Sphenisciformes), represented at least by two morphotypes of different size, also large-sized penguins of the genus $\mathrm{Pal}$ aeeudyptes, and a fragmentary tibiotarsus referred to a probable indeterminate Ardeidae, all recovered from three units of middle to late Eocene exposed in Magallanes, southernmost Chile (Sallaberry et al., 2010). The low-latitude records are represented by endemic species such as Perudyptes devriesi Clarke et al., 2007, from middle Eocene levels of the Paracas Formation, Peru, and Icadyptes salasi Clarke et al., 2007, recovered from Upper Eocene levels of the
Otuma Formation, Peru. A third endemic species, Inkayacu paracasensis Clarke et al., 2010, was described from Late Eocene levels of the Yumaque Point, in the Paracas reserve, Peru. More recently closer phylogenetic affinities between Peruvian (Inkayacu) and Antarctic Eocene penguins have been suggested, being considered probably congeneric (Jadwiszczak, 2011).

No further Eocene fossil birds are known from the Eastern South Pacific. Here we describe new material from central Chile representing the first non-penguin remains of the Middle to Late Eocene, from intermediate latitude between the Magallanes Region and Perú. Besides the fossil heron from Magallanes, all the Eocene record of birds from the western coast of South America are comprised by penguins (Sphenisciformes).

The materials here described are hosted at the Área de Paleontología, Museo Nacional de Historia Natural, Santiago de Chile under the acronym SGO.PV.

\section{Locality and Geological Setting}

The studied specimens were collected at the coastal town of Algarrobo ( $\left.33^{\circ} 22^{\prime} \mathrm{S} ; 71^{\circ} 40^{\prime} \mathrm{W}\right)$ in central Chile, placed aproximately $120 \mathrm{~km} \mathrm{~W}$ from Santiago (Fig. 1). In this locality, a discrete sequence of sedimentary sequence rocks is exposed along the coastal line, belonging to two different units:

\subsection{Estratos de la Quebrada Municipalidad (Gana et al., 1996).}

Discrete succession of transgressive, marine beds that extends about $40 \mathrm{~m}$ along the coastal shore. It is mainly conformed by sandstones, with some frequently glauconitic levels and fine conglomerate lenses (Fig. 1). This unit was assigned to the Maastrichtian based on representative fossils invertebrates such us Cardium (Bucardium) acuticostatum (D'Orbigny), Pacitrigonia hanetiana (D’Orbigny), Grossouvreites sp. and Pachydiscus sp. (Tavera, 1980), and a radioisotopic date obtained from bivalvian shells (Suárez and Marquardt, 2003) that indicates $69 \pm 01 \mathrm{Ma}$. The fossil assemblage is also comprised by abundant vertebrates including a few actinopterygian fishes (e.g., aspidorhynchids; Brito and Suárez, 2003), a great diversity of elasmobranchs (e.g., Odontaspididae, Palaeospinacidae, Squatinidae, Squalidae, Echinorhinidae, Schlerorhynchidae, Dasyatidae, 


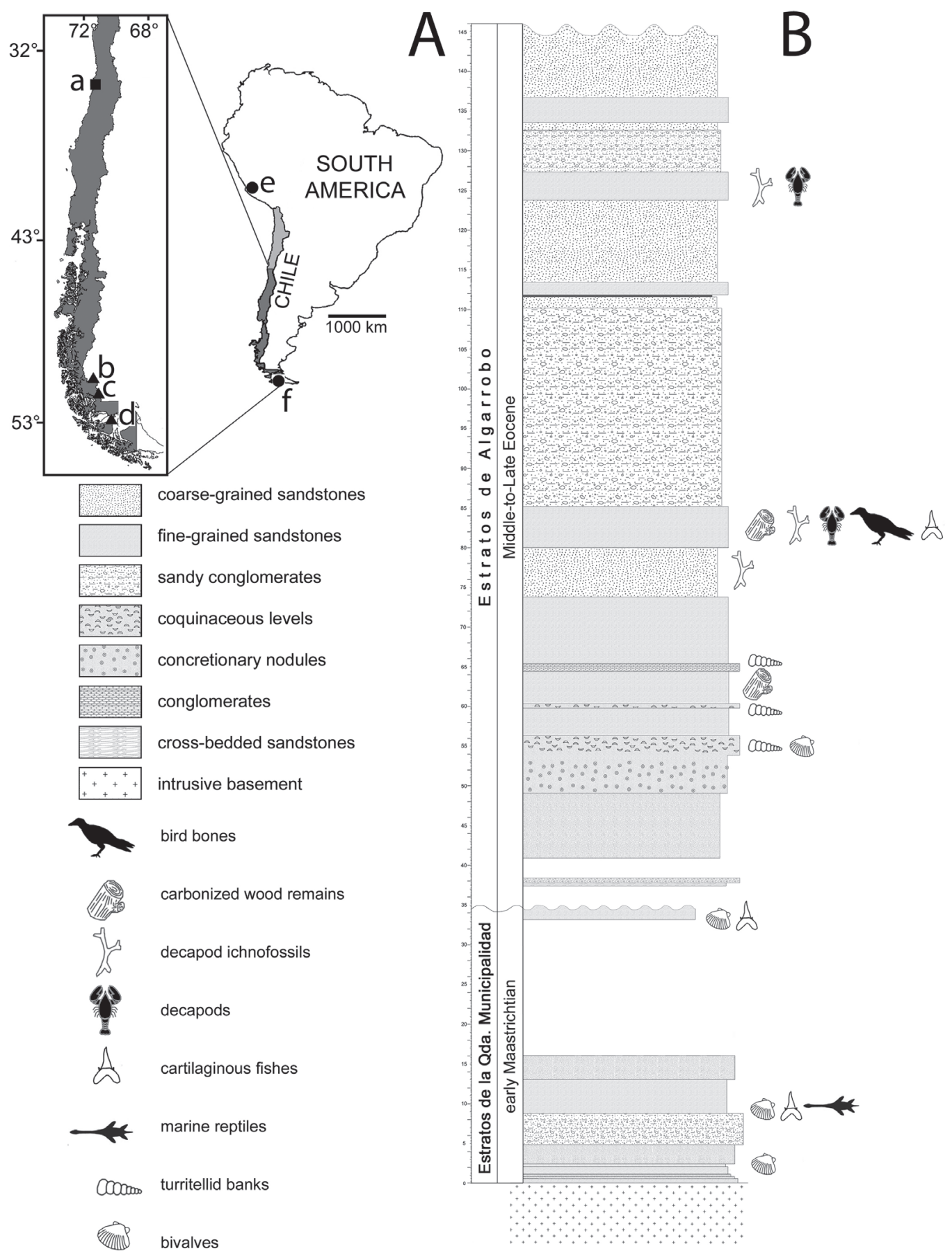

FIG. 1. 1. Schematic map of most relevant Eocene units with fossil bird remains along Chile and South America. A. Algarrobo, Valparaíso Region, marked with a square, indicating the locality of provenance of the studied specimens. Estratos de Algarrobo, Middle to Late Eocene; B. Sierra Baguales. Río Baguales Formation, Middle to Late Eocene; C. Sierra Dorotea. Río Turbio Formation, Middle to Late Eocene; D. Punta Arenas. Loreto Formation, Middle to Late Eocene. Other Eocene localities in South America with fossil birds; E. Ica, Perú. Otuma and Paracas formations, Middle to Late Eocene; F. Tierra del Fuego, Argentina. Leticia Formation, Middle Eocene. 2. Stratigraphic scheme of the studied section exposed at Algarrobo, based on Tavera (1980) and present field observations, including the hosting level of the studied material. 
Callorhynchidae and Chimaeridae; Suárez et al., 2003; Suárez and Cappetta, 2004; Otero and Suárez, 2009) and marine reptiles (e.g., elasmosaurid plesiosaurs, cf. dermochelyid turtles and indeterminate mosasaurs; Otero et al., in 2012).

Fossil invertebrates are also abundant (Philippi, 1887; Brüggen, 1915). Finally, scarce carbonized wood remains can be often observed.

\subsection{Estratos de Algarrobo (Gana et al., 1996).}

This succession is conformed by sandstones of variable grain size and hardness, very fossiliferous, with abundant concretionary nodules in different levels. It is exposed for approximately $150 \mathrm{~m}$ along the coast (95 m of thickness) and overlies the Estratos de la Quebrada Municipalidad through an erosive discordance (Fig. 1). The roof of the unit is constrained by a granitic basement through an inferred fault. This unit was assigned to the Middle to Late Eocene based on fossil invertebrates with good chronostratigraphic resolution (Brüggen 1915; Tavera, 1980). Additionally, endemic fossil crustaceans have been described from this unit (Schweitzer et al., 2006).

The fossil specimens here studied were collected from this unit, associated to dental plates of rays (Myliobatis sp.), being later prepared at the Museo Nacional de Historia Natural, Santiago, during 2009.

\section{Systematic Paleontology}

Aves Linnaeus, 1758

Ornithurae Haeckel, 1866

Neornithes Gadow, 1893

Neornithes indet.

Fig. 2

Material: SGO.PV 1024a: Distal fragment of right femur, SGO.PV.1024b: proximal end of right femur. Collected by one of the authors (MES).

Horizon and age: Estratos de Algarrobo (Gana et al., 1996), Middle to Late Eocene.

Description: The anatomical nomenclature follows Baumel and Witmer (1993). The distal portion (SGO. PV.1024a) preserves both condyli, being eroded in their medial and lateral surfaces. The condylus medialis is smaller than the condylus lateralis and it is projected medially. The condylus lateralis extends distally beyond the condylus medialis. In lateral view the trochlea fibularis have a more
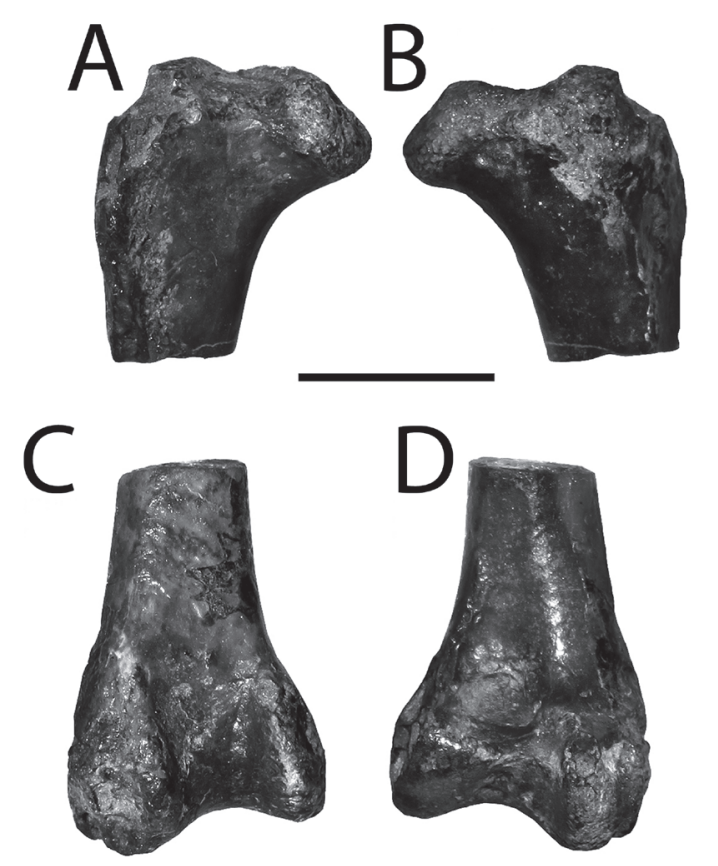

FIG. 2. SGO.PV 1024; Unassociated proximal and distal fragments of right femur A. cranial view of proximal end; B. caudal view of proximal end; C. caudal view of distal end; D. cranial view of distal end. Scale bar $=10 \mathrm{~mm}$.

lateral position than the condylus lateralis. In the caudal view, the impressio ligamentaris cruciati cranialis and the impressio ligamentaris cruciati caudalis are both visible. The fossa poplitea is deep and well defined by a distal ridge. The crista tibiofibularis is conspicuous but poorly preserved. The tuberculum musculi gastrocnemialis lateralis appears in a lateral position. The crista supracondylaris medialis is present but eroded. In caudal view, a broad sulcus patellaris and a deep sulcus intercondylaris are present, but the impression ligamentaris collateralis lateralis and the fovea tendineus of the musculi tibialis cranialis are lost due to erosion. The preserved portion of the diaphysis has a subcircular cross section. The measurements of the distal fragment are: maximum preserved proximal-distal length from the condylus lateralis $18.92 \mathrm{~mm}$, width of condylus lateralis $4.86 \mathrm{~mm}$, cranio caudal width of condylus lateralis $10.64 \mathrm{~mm}$, cranio caudal width of the sulcus intercondylaris $6.36 \mathrm{~mm}$, width of condylus medialis $4.89 \mathrm{~mm}$, cranio caudal width of condylus lateralis $8.85 \mathrm{~mm}$, cranio caudal width of the diaphysis $5.49 \mathrm{~mm}$, width of sulcus patellaris $4.58 \mathrm{~mm}$. 
The proximal fragment (SGO.PV.1024b) is strongly eroded in the most proximal segment. In cranial aspect, the crista trochanteris is incomplete and the surfaces of the facies articularis antitrochanterica are eroded, but extended craniocaudally. The fossa trochanteris, facies articularis acetabularis, and trochanter femoris cannot be appreciated due to preservation. The impression musculi obturatoriae is present but eroded. Caput femoris is well developed while the fovea ligamentaris capitis is poorly preserved (Fig. 3). The measurements of the proximal fragment are maximum preserved proximal-distal length $18.92 \mathrm{~mm}$, cranio caudal width of the diaphysis $5.60 \mathrm{~mm}$, proximal width from the caput femoris to the crista trochanteris $13.62 \mathrm{~mm}$, cranio caudal width of the caput femoris $5.77 \mathrm{~mm}$, proximal cranio caudal width above facies articularis antitrochanterica $6.78 \mathrm{~mm}$.
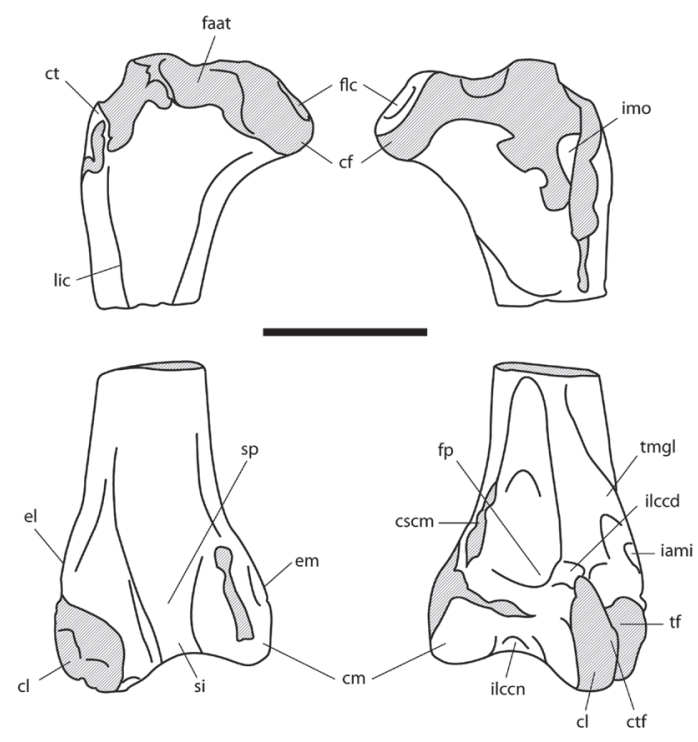

FIG. 3. Anatomical nomenclature according to Baumel and Witmer (1993). cf: caput femoris; cl: condylus lateralis; cm: condylus medialis; $\mathbf{c s c m}$ : crista supracondylaris medialis; ct: crista trochanteris; ctf: crista tibiofibularis; el: epicondylus lateralis; em: epicondylus medialis; faat: facies articularis antitrochanterica; flc: fovea ligamentaris capitis; fp: fossa poplitea; iami: impression ansae musculi iliofibularis; ilccd: impression ligamentaris cruciati caudalis; ilccn: impression ligamentaris cruciati cranialis; imo: impression musculi obturatoriae; lic: linea intermuscularis cranialis; si: sulcus intercondylaris. sp: sulcus patellaris; tf: trochea fibularis; tmgl: tuberculum musculi gastrocnemialis lateralis. Scale bar $=10 \mathrm{~mm}$.

\section{Discussion}

In the distal fragment, the presence of the impressio ansae musculi fibularis (Hutchinson, 2001) as well as conspicuous fossa poplitea (Chiappe, 1996), are diagnostic in the Ornithothoraces. On the other hand, the sulcus intercondylaris with a deep proximal depression (sulcus patellaris) is characteristic of the clade Ornithurae (Hesperornithiformes+Ichtyorniti formes and Neornithes) (Chiappe, 1996).

Despite the fragmentary condition of SGO.PV 1024, the presence of traits such as lateral crista trochanteris confirms its assignment to Ornithurae (Chiappe, 1995). However, the facies articularis antitrochanterica extended in cranio-caudal sense, as observed in the studied specimen, is a probable synapomorphy of Neornithes (Hope, 2002). Although the crista trochanteris is eroded, in SGO.PV 1024 it preserves its proximal portion, allowing us to distinguish it from some birds such as 'Pelecaniformes' which lack an elevation of the crista trochanteris (Hope, 2002). The shape of the cross section, the preserved diaphysis in SGO.PV 1024 allows us to discard affinities with Gaviiformes, which have well-defined borders and a laterally compressed femur (Baumel and Witmer, 1993). On the other hand, Sphenisciformes have a femur with a flattened lateral side in proximal portion, without convexity, unlike SGO.PV 1024, discarding that the fossil could represent a penguin.

The lack of pneumatic foramen in craniolateral side of the proximal end of femur is considered a plesiomorphy in several clades within Neornithes (Hutchinson, 2001; Mayr and Clarke, 2003). An apomorphic condition is independently founded in Cracidae, Phasianidae, Anhimidae, Phoenicopteridae, Ciconiidae, Otididae from the 'land birds clade' or Node F sensu Hackett et al. (2008) (Mayr and Clarke, 2003), supporting the exclusion of SGO.PV 1024 from these derivate clades of Neornithes.

Based on general proportions and morphology, the specimens described here resemble some groups of aquatic birds. Morphologically, SGO.PV 1024a and SGO.PV 1024b have similar femora to Procellariiformes and 'Ciconiiformes', these birds comprises the Node H the 'water birds clade' sensu Hackett et al. (2008) a monophyletic unit of aquatic birds recovered in several phylogenetic analysis (Mayr, 2011), but also the similarity of SGO.PV 
1024 with Podicipediformes and Charadriiformes do not allow to nested unequivocally within the 'water birds clade' sensu Hackett et al. (2008). We prefer to assign both specimens to a more inclusive taxonomical level due to the absence of unambiguous synapomorphies. Nevertheless, we attempt to associate with high probabilities, SGO.PV 1024 specimen with a marine bird such as a small procelarid. Figure 4 shows that the lack of a strong ridge in the caput femoris is shared with all procelarid birds used for comparison (Daption capense, Fulmarus glacialis, Pelecanoides garnotti, and Pachyptila belcheri) as well as the high of the most proximal portion of the bone, supporting the temptative determination as a procelarid bird.

Fossil vertebrates are not frequent in the Eocene outcrops at Algarrobo, and to date, they are only represented by disarticulated and fragmentary materials. The presence of bird remains is an extremely rare finding. It is possible that the two fragments of femur SGO.PV 1024 could represent a unique individual, considering the very low frequence of vertebrate remains in the hosting beds. Moreover, the proximity of the finding of the fragment in the field, plus the morphometric comparison of the distal and proximal ends, particularly the similar cranio caudal width of the diaphysis, strongly suggest that they would belong to the same individual.

Bird bones in Algarrobo have an special paleobiogeographic relevance. It is the first record of this kind in Middle-Late Eocene levels of central Chile. This locality is important because its intermediate location between the Magallanes Region (Sallaberry et al., 2010), Tierra del Fuego (Clarke et al., 2003), Antarctica (Myrcha et al., 2002; Jadwiszczak, 2006; Tambussi and Acosta Hospitaleche, 2007) and those from Peru during the same time interval (Acosta Hospitaleche and Stucchi, 2005; Clarke et al., 2007; Clarke et al., 2010). Eocene record of birds from southernmost South America and its Pacific coast is comprised almost exclusively by Sphenisciformes (Clarke et al., 2003; Acosta Hospitaleche and Stucchi, 2005; Clarke et al., 2007; Clarke et al., 2010; Sallaberry et al., 2010), while the specimens here studied are assignable to a different order of Neornithes. Because we are here dealing with isolated bones, it is preferred to avoid risky taxonomic assignments, employing a conservative criteria (see Ksepka and Cracraft, 2008); nevertheless, it is important to recall that SGO.PV 1024 would represent an aquatic bird.
Biogeographically, the opening of the Drake Passage and the Tasman Rise diminished the main seaway that crossed from eastern Australia, through western Antarctica and into southern South America (Lawver and Gahagan, 2003). This seaway was the main factor to keep the ecological affinities of marine vertebrate assemblages along different localities of the Weddellian Biogeographic Province (Zinsmeister, 1979). Endemic assemblages seem to be restricted to shallower waters, suggesting that these occurred as a consequence of local biogeographic barriers. The establishment of the Antarctic circumpolar current during the Late Eocene probably as a consequence of the Drake Passage nearly $41 \mathrm{Ma}$ (Scher and Martin, 2006), and the later beginning of the Humboldt Current during the Miocene, provided new and more stable environmental conditions that favoured closer ecologic affinities between marine vertebrates along the Pacific in lower latitudes. This suggests a partial hypothesis of why spheniscid species in Chile and Perú had closer affinities during the Neogene rather than during the Paleogene, being represented by several common species, but retaining the presence of the circumpolar, extant genus Pygoscelis in northern Chile as a remarkable difference (Acosta Hospitaleche et al., 2006; Walsh and Suárez, 2006; Sallaberry et al., 2008). This record could probably indicate that a biogeographical barrier existed during the Eocene in the Pacific coast of South America, suggesting that Eocene penguins from Peru have a vicariant origin.

Penguins are often the most frequent birds in avian fossil assemblages when they are present (Cruz, 2007). In the case of the studied specimens, the presence of the fragmentary bird bones is also relevant for the local record, since vertebrate remains in the Estratos de Algarrobo are very scarce, and to date, only represented by dental plates of rays (Suárez and Marquardt, 2003) and isolated fish remains (Tavera, 1980). On the other hand, invertebrate fossils from the same unit are very abundant and diverse, being mainly represented by bivalves, gastropods, echinoderms and nautilids (Brüggen, 1915; Tavera, 1980), less frequently by endemic decapods, ichnofossils referred to Ophiomorpha sp. and Thalassinoides sp. (Schweitzer et al., 2006), and relatively abundant wood remains, among others. This fossil assemblage suggest sub-tidal, shallow marine conditions for the deposit, while the presence of fragmentary wood remains indicates a possible deltaic environment, 


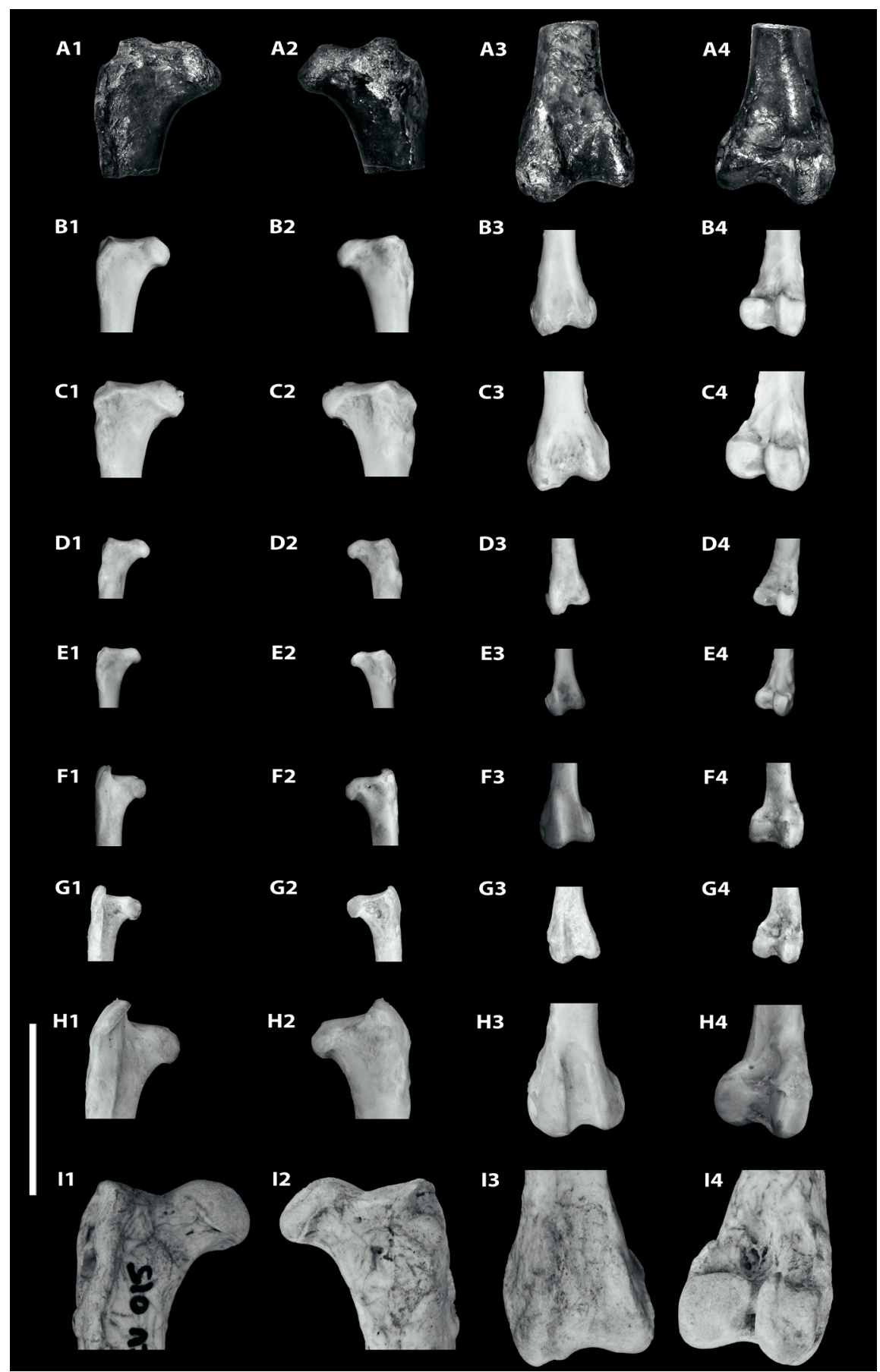

FIG. 4. Comparison between the studied remains and several femora of extant aquatics birds: A1-A4. SGO.PV 1024 Neornithes indet; B1-B4. Cape Petrel, Daption capense; C1-C4. Northern Fulmar, Fulmarus glacialis; D1-D4. Peruvian Diving-petrel, Pelecanoides garnotti; E1-E4. Slender-billed Prion, Pachyptila belcheri; F1-F4. Franklin's Gull, Larus pipixcan; G1-G4. Elegant Tern, Sterna elegans; H1-H4. Guanay Cormorant, Phalacrocorax bougainvillii; I1-I4. Humboldt penguin, Spheniscus humboldti. Proximal portion of femora in cranial (A1, B1, C1, D1, E1, F1, G1, H1, I1) and caudal view (A2, B2, C2, D2, E2, F2, G2, H2, I2). Distal portion of femora in cranial (A3, B3, C3, D3, E3, F3, G3, H3, I3) and caudal view (A4, B4, C4, D4, E4, F4, G4, H4, I4). Scale bar $=20 \mathrm{~mm}$. 
as previously proposed by Schweitzer et al. (2006). This can explain the absence of articulated or more complete vertebrate remains, and the mixed occurrence of intertidal fauna with open sea organisms such as nautiloids. Similar environmental conditions including marine fauna and indicators of proximity to the coast are also observed in all Eocene outcrops at Magallanes Region. Bird remains occur together with elasmobranch teeth and abundant invertebrates, mostly bivalves with several common genera present both in Magallanes and Algarrobo (Tavera, 1946). Also, as pointed out by Sallaberry et al. (2010), there is a certain level of correlation between Estratos de Algarrobo and the Eocene units in Magallanes and Vicecomodoro Marambio Island (Seymour Island, Antarctica).

The present find verifies the need of more field work at the Estratos de Algarrobo, that could help to establish paleoecologic connections (or differences) between the northernmost Eocene outcrops of the Weddellian Biogeographic Province and low-latitude localities in Peru, helping to understand the possible northern limits of the mentioned Province and the impact of the opening of the Drake Passage in the local faunas.

\section{Acknowledgments}

R.E. Yury-Yáñez, R.A. Otero and D. Rubilar-Rogers are supported by the Antarctic Ring Bicentenary Project (Proyecto Bicentenario de Ciencia y Tecnología Anillo Antártico, PBCT-ARTG-04, Conicyt, Chile), and the current project ACT-105 Conicyt-Chile, both directed by Dr. T. Torres. All extant birds were reviewed from the Osteological Collection of the Vertebrate Zoology Laboratory from the Facultad de Ciencias-Universidad de Chile. M.E. Suárez and R.A. Otero are authorized by the Consejo de Monumentos Nacionales (National Council of Monuments) on March 2006, point 172, for collecting samples from the studied locality. Also R.E. Yury-Yáñez is granted with a Conicyt scolarship for Master's studies in Chile (Programa de Formación de Capital Humano Avanzado).

\section{References}

Acosta Hospitaleche, C. 2005. Systematic revision of Arhrodytes Ameghino, 1905 (Aves, Spheniscidae) and its assignment to the Paraptenodytinae. Neues Jahrbuch für Geologie und Paläontologie, Monatshefte 7: 404-414.
Acosta Hospitaleche, C.; Stucchi, M. 2005. Nuevos restos terciarios de Spheniscidae (Aves, Sphenisciformes) procedentes de la costa del Perú. Revista Española de Paleontología 20: 1-5.

Acosta Hospitaleche, C.; Chávez, M.; Fritis, O. 2006. Pingüinos fósiles (Pygoscelis calderensis nov. sp.) en la Formación Bahía Inglesa (Mioceno Medio- Plioceno), Chile. Revista Geológica de Chile 33: 327-338.

Alvarenga, H. 1995. A large and probably fligthless Anhinga from the Miocene of Chile. In Proceedings of the 3rd Symposium of the Society of Avian Paleontology and Evolution (Peters, D.S.; editor) Courier Forschungsinstitut Senckenberg 181: 149161. Frankfurt am Main.

Ameghino, F. 1895. Sur les oiseaux fossiles de Patagonie. Boletín del Instituto Geográfico (Argentina) 15: 501-602.

Ameghino, F. 1901. Enumeración de los impennes fósiles de Patagonia y de la Isla Seymour. Anales del Museo Nacional de Buenos Aires 3: 97-167.

Baumel, J.; Witmer, L.M. 1993. Osteology. In Handbook of avian anatomy: Nomina Anatomica Avium (Baumel, J.; King, A.; Breazile, J.E.; Evans, H.; Vanden Bergue, J.C.; editors). Cambridge University Press: 45-132. Cambridge, Massachusetts, USA.

Brito, P.M.; Suárez, M.E. 2003. Late Cretaceous Belonostomus (Pisces, Actinopterygii, Aspidorhynchidae) from Algarrobo, Chile, with comments on aspidorhynchid paleodistribution in South America. Revista Geológica de Chile 30 (1): 117-127.

Brüggen, J. 1915. El Cretáceo de Algarrobo. Sociedad Imprenta Litográfica Barcelona: $15 \mathrm{p}$. Santiago-Valparaíso.

Chávez, M. 2007. Fossil birds of Chile and Antarctic Peninsula. Arquivos do Museu Nacional, Rio de Janeiro 65: 551-572.

Chiappe, L.M. 1995. The phylogenetic position of the Cretaceous birds of Argentina: Enantiornithes and Patagopteryx deferrariisi. In Proceedings of the 3rd Symposium of the Society of Avian Paleontology and Evolution (Peters, D.S.; editor). Courier Forschungsinstitut Senckenberg 181: 55-63. Frankfurt am Main.

Chiappe, L.M. 1996. Late Cretaceous birds of southern South America: anatomy and systematics of $\mathrm{Pa}$ tagopteryx and Enantiornithes. In Contributions of southern South America to Vertebrate Paleontology (Arratia, G.; editor). Münchner Geowissenschaftliche Abhandlungen (A) 30: 203-244.

Clarke, J.A.; Olivero, E.B.; Puerta, P. 2003. Description of the Earliest Fossil Penguin from South America and First Paleogene Vertebrate Locality of Tierra del Fuego, Argentina. American Museum Novitates 3423: 1-18. 
Clarke, J.A.; Ksepka, D.T.; Stucchi, M.; Urbina, M.; Giannini, N.; Bertelli, S.; Narváez, Y.; Boyd, C.A. 2007. Paleogene equatorial penguins challenge the proposed relationship between biogeography, diversity and Cenozoic climate change. Proceedings of the National Academy of Sciences, USA 104 (20): 11545-11550.

Clarke, J.A.; Ksepka, D.T.; Salas-Gismondi, R.; Altamirano, A.J.; Shawkey, M.D.; D’Alba, L.; Vinther, J.; DeVries, T.J.; Baby, P. 2010. Fossil Evidence for Evolution of the Shape and Color of Penguin Feathers. Science 330: 954-957.

Cruz, I. 2007. Avian taphonomy: observations at two Magellanic penguin (Spheniscus magellanicus) breeding colonies and their implications for the fossil record. Journal of Archaeological Science 34: 1252-1261.

Emslie, S.D.; Guerra Correa, G. 2003. A new species of penguin (Spheniscidae: Spheniscus) and other birds from the late Pliocene of Chile. Proceedings of the Biological Society of Washington 116: 308-316.

Ferraris, F.; Di Biase, F. 1978. Hoja de Antofagasta, Región de Antofagasta. Instituto de Investigaciones Geológicas, Carta Geológica de Chile 30: 48 p., escala 1:250.000. Santiago.

Gana, P.; Wall, R.; Gutiérrez, R. 1996. Mapa Geológico del área Valparaíso-Curacaví, Región de Valparaíso y Región Metropolitana. Servicio Nacional de Geología y Minería, Mapa Geológico 1: 20 p., escala 1:100.000. Santiago.

Hackett, S.J.; Kimball, R.T.; Reddy, S.; Bowie, R.C.K.; Braun, E.L.; Braun, M.J.; Chojnowsky, J.L.; Cox, W.A.; Han, K.-L.; Harshman, J.; Huddleston, C.J.; Marks, B.D.; Miglia, K.J.; Moore, W.S.; Sheldon, F.H.; Steadman, D.W.; Witt, C.C.; Yuri, T. 2008. A phylogenomic study of birds reveals their evolutionary history. Science 320: 1763-1767.

Hope, S. 2002. The Mesozoic radiation of Neornithes. In Mesozoic Birds: Above the Heads of Dinosaurs (Chiappe, L.M.; Witmer,L.M.; editors) University of California Press, Berkeley: 339-388. California.

Hutchinson, J.R. 2001. The evolution of femoral osteology and soft tissues on the line to extant birds (Neornithes). Zoological Journal of the Linnean Society 131: 169-197.

Jadwiszczak, P. 2006. Eocene penguins of Seymour Island, Antarctica: Taxonomy. Polish Polar Research 27 (1): 3-62.

Jadwiszczak, P. 2009. Penguin past: The current state of knowledge. Polish Polar Research 30 (1): 3-28.

Jadwiszczak, P. 2011. New data on morphology of late Eocene penguins and implications for their geographic distribution. Antarctic Science Available on CJO 2011 doi:10.1017/S0954102011000526.

Ksepka, D.T.; Cracraft, J. 2008. An avian tarsometatarsus from near the K/T boundary of New Zealand. Journal of Vertebrate Paleontology 28 (4): 1224-1227.

Lawver, L.; Gahagan, L. 2003. Evolution of Cenozoic seaways in the circum-Antarctic region. Palaeogeography, Palaeoclimatology, Palaeoecology 198: 11-37.

Marquardt, C.; Blanco, N.; Godoy, E.; Lavenu, A.; Ortlieb, L.; Marchant, M.; Guzmán, N. 2000. Estratigrafía del Cenozoico Superior en el área de Caldera (2645'$\left.28^{\circ} \mathrm{S}\right)$, III Región de Atacama. In Congreso Geológico Chileno, No. 9, Actas: 504-508. Puerto Varas.

Mayr, G. 2011. Metaves, Mirandornithes, Strisores and other novelties-a critical review of the higher-level phylogeny of neornithine birds. Journal of Zoological Systematics and Evolutionary Research 49: 58-76

Mayr, G.; Clarke, J. 2003. The deep divergences of neornithine birds: a phylogenetic analysis of morphological characters. Cladistics 19: 527-553.

Mayr, G.; Rubilar Rogers, D. 2010. Osteology of a new giant bony-toothed bird from the Miocene of Chile, with a revision of the taxonomy of Neogene Pelagornithidae. Journal of Vertebrate Paleontology 30: 1313-1330.

Moscoso, R.; Nasi, C.; Salinas, P. 1982. Geología de la Hoja Vallenar y parte norte de La Serena, Regiones de Atacama y Coquimbo. Servicio Nacional de Geología y Minería, Carta Geológica de Chile 55: 100 p., 1 mapa escala 1:250.000.

Myrcha, A.; Jadwiszczak, P.; Tambussi, C.P.; Noriega, J.I.; Gazdzicki, A.; Tatur, R.; Del Valle, R. 2002. Taxonomic revision of Eocene Antarctic penguins based on tarsometatarsal morphology. Polish Polar Research 23 (1): 5-46.

Niemeyer, H.; Muñoz, J. 1983. Hoja Laguna de La Laja. Servicio Nacional de Geología y Minería Carta Geológica de Chile 57: 52 p., 1 mapa escala 1:250.000.

Otero, R.A.; Suárez, M.E. 2009. Primer registro de tiburón espinoso (Squaliformes; Echinorhinidae) en el Cretácico Superior (Maastrichtiano) de Chile y Sudamérica. In Primer Simposio Paleontología en Chile, Libro de Actas: 74-77. Santiago.

Otero, R.A.; Parham, J.F.; Suárez, M.E.; Soto-Acuña, S.; Jiménez-Huidobro, P.; Rubilar-Rogers, D. 2012. Marine reptiles from the Late Cretaceous (early Maastrichtian) of Algarrobo, central Chile. Cretaceous Research 35: 124-132.

Philippi, R.A. 1887. Los Fósiles Terciarios i Cuartarios de Chile. F.A. Brockhaus print: 236 p. Leipzig. 
Rojo, M. 1985. Un aporte al conocimiento del Terciario marino: Formación Bahía Inglesa. In Congreso Geológico Chileno, No. 4, Actas 1: 514-533. Antofagasta.

Sallaberry, M.; Rubilar-Rogers, D.; Suárez, M.E.; Gutstein, C.S. 2007. The skull of a fossil Prion (Aves: Procellariiformes) from the Neogene (Late Miocene) of northern Chile. Revista Geológica de Chile 34 (1): 147-154.

Sallaberry, M.; Yury-Yáñez, R.E.; Soto-Acuña, S.; RubilarRogers, D. 2008. Las aves fósiles de la Formación Bahía Inglesa: hallazgos y perspectivas. In Primer Simposio Paleontología en Chile, Libro de Actas: 109-115. Santiago.

Sallaberry, M.A.; Yury-Yáñez, R.E.; Otero, R.A.; SotoAcuña, S.; Torres,T. 2010. Eocene birds from the western margin of southernmost South America. Journal of Paleontology 84: 1061-1070.

Scher, H.D.; Martin, E.E. 2006. Timing and climatic consequences of the opening of Drake Passage. Nature 312: 428-430.

Schweitzer, C.E.; Feldmann, R.M.; Encinas, A.; Suárez, M.E. 2006. New Cretaceous and Eocene Callianassoidea (Thalassinidea, Decapoda) from Algarrobo, Chile. Journal of Crustacean Biology 26: 73-81.

Suárez, M.E.; Cappetta, H. 2004. Sclerorhynchid teeth (Neoselachii, Sclerorhynchidae) from the Late Cretaceous of the Quiriquina Formation, central Chile. Revista Geológica de Chile 31 (1): 89-103.

Suárez, M.E.; Marquardt, C. 2003. Revisión preliminar de las faunas de peces elasmobranquios del Mesozoico y Cenozoico de Chile y comentarios sobre su valor cronoestratigráfico. In Congreso Geológico Chileno, No. 10, Sección temática 3, CD-ROM. Concepción.

Suárez, M.E.; Quinzio, L.A.; Fritis, O.; Bonilla, R. 2003. Aportes al conocimiento de los vertebrados marinos de la Formación Quiriquina. In Congreso Geológico Chileno, No. 10, Resúmenes, CD-ROM. Concepción.

Tambussi, C.P.; Acosta Hospitaleche, C. 2007. Antarctic Birds (Neornithes) during the Cretaceous-Eocene times. Revista de la Asociación Geológica Argentina 62: 604-617.

Tavera, J. 1946. Las migraciones de fauna entre el Senoniano Superior y Terciario y la fauna santoniana y terciaria de Magallanes. In Anais Segundo Congreso Panamericano de Engehnaria de Minas e Geología, Tesis, Petropolis: 171 p. Brazil.

Tavera, J. 1980. El Cretáceo y Terciario de Algarrobo. Imprentas Gráficas: 53 p. Santiago.

Walsh, S.; Hume, J. 2001. A new Neogene marine avian assemblage from north-central Chile. Journal of Vertebrate Paleontology 21: 484-491.

Walsh, S.; Suárez, M.E. 2006. New penguin remains from the Pliocene of northern Chile. Historical Biology 18: 115-126.

Zinsmeister, W.J. 1979. Biogeographic significance of the Late Mesozoic and early Tertiary molluscan faunas of Seymour Island (Antarctic Peninsula) to the final break-up of Gondwanaland. In Historical Biogeography, Plate Tectonics and the Changing Environment (Gray, J.; Boucot, A.J.; editors). Oregon State University Press: 349-355. Corvallis.

Manuscript received: July 11, 2011; revised/accepted: October 20, 2011; available online: June 19, 2012. 